\title{
Sistem Informasi Objek Wisata dengan Algoritma Djisktra untuk Rute Terdekat dan Metode Analitycal Hierarchy Process (AHP) untuk Rekomendasi. (Studi Kasus Kabupaten Bengkayang)
}

\author{
Sandra Permata Gea Setiawan ${ }^{\mathrm{a} 1}$, Herry Sujaini ${ }^{\mathrm{a} 2}$, M. Azhar Irwansyah ${ }^{\mathrm{a} 3}$ \\ a Program Studi Informatika Fakultas Teknik Universitas Tanjungpura \\ Jl. Prof. Dr. H. Hadari Nawawi, Kota Pontianak, 78115 \\ ${ }^{1}$ sandrapermatagea@gmail.com \\ 2hsduntan.ac.id \\ 3irwansyah.azhareuntan.ac.id
}

\begin{abstract}
Abstrak
Pariwisata merupakan suatu perjalanan yang dilakukan orang untuk sementara waktu dengan tujuan menikmati kegiatan pertamasyaan dan rekreasi atau memenuhi keinginan yang beraneka ragam.Kabupaten Bengkayangadalah salah satu kabupaten di provinsi Kalimantan Barat, Indonesia. Sebelumnya merupakan pemekaran dari Kabupaten Sambas yang karena adanya Undang-undang Otonomi Daerah dimekarkan menjadi 3 daerah otonom yang terpisah, yaitu Kabupaten Sambas, Kabupaten Bengkayang dan Kota Singkawang. Terletak di bagian utara Kalimantan Barat, Kabupaten Bengkayang berbatasan langsung dengan Sarawak, Malaysia. Bengkayang memiliki sektor pariwisata memegang peranan penting dalam perekonomian daerah ini. Pemerintah Kabupaten Bengkayang memiliki masalah dan kesulitan dalam menyampaikan informasi yang berkaitan tentang pariwisata yang ada di kabupaten Bengkayang, karena tidak adanya media informasi yang dapat dengan mudah di akses oleh publik. Pemerintah Kabupaten Bengkayang selama ini kesulitan dalam memberikan informasi jalur terdekat menuju tempat wisata dan rekomendasi wisata yang ada. Metode Analitycal Hierarchy Process (AHP) dan Algoritma Dijkstra digunakan dalam sistem untuk menampilkan rute jalur terdekat dan rekomendasi objek wisata. Dengan sistem informasi objek wisata yang memanfaatkan dua metode tersebut, Pemerintah Kabupaten Bengkayang dapat membantu wisatawan untuk mendapatkan informasi mengenai objek wisata di Kabupaten Bengkayang. Hasil dari penelitian ini sistem informasi objek wisata ini dapat memberikan informasi rekomendasi dan jalur wisata yang ada di kabupaten Bengkayang.
\end{abstract}

Kata kunci: Pariwisata, Bengkayang, Analitycal Hierarchy Process, Algoritma Dijkstra, Sistem Informasi.

\section{Tourist Information System with the Djisktra Algorithm for the Nearest Route and the Analytical Hierarchy Process (AHP) Method for Recommendations.}

\begin{abstract}
(Bengkayang Regency Case Study)Tourism is a journey that is carried out by people for a while with the aim of enjoying leisure and recreational activities or fulfilling diverse desires. Bengkayang Regency is one of the districts in the province of West Borneo, Indonesia. Previously it was a division of Sambas Regency, which due to the Regional Autonomy Law, was divided into three separate autonomous regions, namely Sambas Regency, Bengkayang Regency, and Singkawang City. Located in the northern part of West Borneo, Bengkayang Regency is directly adjacent to Sarawak, Malaysia. Bengkayang has a tourism sector that plays an essential role in the economy of this area. Bengkayang Regency Government has problems and difficulties in conveying information related to tourism in Bengkayang Regency because there is no information media that can be easily accessed by the public. The Bengkayang Regency Government has been struggling to provide information on the nearest route to tourist attractions and existing tourism recommendations. Analytical Hierarchy Process (AHP) method and Dijkstra's algorithm are used in the system to display the nearest route and tourist attraction recommendations. With a tourist information system that utilizes these two methods, the Bengkayang Regency Government can help tourists to get information about attractions in Bengkayang Regency. The results of this
\end{abstract}


research tourist information system can provide information on recommendations and existing tourist routes in Bengkayang Regency.

Keywords: Tourism, Bengkayang, Analytical Hierarchy Process, Dijkstra Algorithm, Information System.

\section{PENDAhUluAN}

Kabupaten Bengkayang adalah salah satu kabupaten di Kalimantan Barat, yang merupakan pemekaran dari Kabupaten Sambas yang karena adanya Undang-undang Otonomi Daerah, tiga daerah otonom yang terpisah, yaitu Kabupaten Sambas, Kabupaten Bengkayang dan Kota Singkawang. Terletak di bagian utara Kalimantan Barat, Kabupaten Bengkayang berbatasan langsung dengan Sarawak, Malaysia. Bengkayang memiliki sektor pariwisata memegang peranan penting dalam perekonomian daerah ini. Pemerintah Kabupaten Bengkayang telah melakukan promosi melalui media masa seperti surat kabar, namun metode tersebut belum cukup untuk menginformasikan kepariwisataan secara meluas kepada wisatawan lokal maupun asing.

Pariwisata adalah perjalanan yang dilakukan oleh seseorang dalam jangka waktu tertentu dari suatu tempat ke tempat lain dengan melakukan perencanaan sebelumnya, tujuannya untuk rekreasi atau untuk suatu kepentingan sehingga keinginannya dapat terpenuhi. Pariwisata merupakan salah satu aset yang sangat potensial untuk menambah pendapatan daerah. Dengan adanya pariwisata memiliki dampak positif bagi penduduk antara lain: menambah penghasilan dengan cara berdagang dan masyarakat dapat membuka jasa pemotretan untuk wisatawan yang berkunjung. Ada beberapa jenis pariwisata di Kabupaten Bengkayang antara lain wisata pantai, wisata pulau, wisata alam, wisata budaya dan wisata sejarah. Pemerintah Kabupaten Bengkayang memiliki masalah dan kesulitan dalam menyampaikan informasi yang berkaitan tentang pariwisata yang ada di Kabupaten Bengkayang, karena tidak adanya media informasi yang dapat dengan mudah di akses oleh publik. Pemerintah Kabupaten Bengkayang selama ini kesulitan dalam memberikan informasi jalur terdekat menuju tempat wisata dan rekomendasi wisata yang ada. Metode Analitycal Hierarchy Process (AHP) dan Algoritma Dijkstra digunakan dalam sistem untuk menampilkan rute jalur terdekat dan rekomendasi objek wisata.

Berdasarkan permasalah yang telah dipaparkan, maka penulis membangun sistem informasi objek wisata dengan menggunakan Metode Analitycal Hierarchy Process (AHP) dan Algoritma Dijkstra, sehingga dapat mempermudah informasi mengenai objek wisata di Kabupaten Bengkayang.

Penyajian informasi dalam bentuk web akan memudahkan masyarakat untuk mengaksesnya. Teknologi Sistem Informasi telah berkembang pesat. Sistem informasi dibuat dengan menggunakan informasi yang berasal dari pengolahan sejumlah data, yaitu data geografis atau data yang berkaitan dengan posisi obyek di permukaan bumi.

Sistem yang di rancang berbasis website bertujuan menghasilkan informasi jalur terdekat dan rekomendasi tempat wisata. Sistem juga dapat mendukung dan meningkatkan pengelolahan data serta promosi wisata yang ada di Kabupaten Bengkayang. Sistem informasi juga dapat memberikan penjelasan tentang peristiwa yang ada di Kabupaten Bengkayang.

\section{STUdi LiTERATUR}

\section{A. Penelitian Terkait}

Penelitian yang berjudul sistem informasi geografis pariwisata berbasis web dan pencarian jalur terpendek dengan algoritma Dijkstra di Timor Leste. Untuk membantu kementerian pariwisata Timor Leste dalam mengembangkan industri pariwisata untuk memperoleh informasi yang mudah diakses dari berbagai tempat melaluir internet. Pemetaan SIG pariwisata berbasis web mengunakan Google Maps dan algoritma Dijkstra untuk mencari jalur terpendek dari satu titik ke titik lain pada suatu graf. Penelitian ini menampilkan peta digital pada web dengan Google Maps API. Web server Apache untuk menangani permintaan user untuk mengambil data dari database MySQL. Web server Apache dan database $M y S Q L$ sudah terintegrasi dalam XAMPP. Algoritma Dijkstra dapat melakukan pencarian jalur terpendek dari posisi titik awal user ke tempat obyek lokasi dengan nilai keakuratan jarak rata-rata $0.03 \%$ terhadap pengukuran. Hasil pencarian rute terpendek berupa jarak, rute perjalanan dan waktu tempuh dengan keceptan rata-rata kendaraan yang ditentukan secara bervariasi [1].

Kemudian penelitian berjudul "Perancangan Aplikasi GIS Pencarian Rute Terpendek Peta Wisata Di Implementasi algoritma Dijkstra pada pencarian rute wisata di kota Manado".Penelitian ini bertujuan untuk memberikan informasi rute terdekat wisata di kota Manado. Penelitian ini memiliki kesamaan dengan penelitian yang akan saya teliti. Dimana sistem yang bekerja dengan meminta input data lokasi asal dari posisi user menuju lokasi wisata terdekat. Selanjutnya dengan algoritma djikstra maka didapati rute terpendek lokasi asal menuju lokasi tujuan [2].

Penelitian tentang "Rancang Bangun Aplikasi Pencarian Rute Terpendek Lokasi Wisata Kuliner Kota Pontianak". Berdasarkan penelitian ini diperoleh bahwa sistem berhasil menerapkan algoritma dijkstra dalam pencarian rute terpendek menuju wisata kuliner di Kota Pontianak yang dapat membantu pengguna untuk menuju tempat wisata kuliner [3].

\section{B. Definisi Wisata}

Wisata adalah "bepergian bersama-sama (untuk memperluas pengetahuan, bersenang-senang dan bertamasya)"[4]. Pariwisata merupakan salah satu asset yang sangat potensial untuk menambah pendapatan daerah. Dengan adanya pariwisata memiliki dampak positif bagi penduduk antara lain : menambah penghasilan dengan cara berdagang dan masyarakat dapat membuka jasa pemotretan untuk wisatawan yang berkunjung. 


\section{Definisi Sistem Informasi}

Ada beberapa pengertian informasi menurut para ahli, diantaranya: Sistem adalah rangkaian dari dua atau lebih komponen-komponen yang saling berhubungan, yang berinteraksi untuk mencapai suatu tujuan tertentu. Informasi adalah data yang berguna yang diolah sehingga dapat dijadikan dasar untuk mengambil keputusan yang tepat [5]. Sistem informasi adalah suatu sistem di dalam suatu organisasi yang mempertemukan kebutuhan pengolahan transaksi harian, mendukung operasi, bersifat manajerial dan kegiatan strategi dari suatu organisasi dan menyediakan pihak luar tertentu dengan laporan-laporan yang diperlukan [6] dalam jurnal Hari Kurnia Hantoro dan Sudarmawan.

\section{Analitycal Hierarchy Process (AHP)}

Analitycal Hierarchy Process (AHP) Adalah metode untuk memecahkan suatu situasi yang komplek tidak terstruktur kedalam beberapa komponen dalam susunan yang hirarki, dengan memberi nilai subjektif tentang pentingnya setiap variabel secara relatif, dan menetapkan variabel mana yang memiliki prioritas paling tinggi guna mempengaruhi hasil pada situasi tersebut [7]. Proses pengambilan keputusan pada dasarnya adalah memilih suatu alternatif yang terbaik. Seperti melakukan penstrukturan persoalan, penentuan alternatif-alternatif, penenetapan nilai kemungkinan untuk variabel aleatori, penetap nilai, persyaratan preferensi terhadap waktu, dan spesifikasi atas resiko. Betapapun melebarnya alternatif yang dapat ditetapkan maupun terperincinya penjajagan nilai kemungkinan, keterbatasan yang tetap melingkupi adalah dasar pembandingan berbentuk suatu kriteria yang tunggal. Peralatan utama Analitycal Hierarchy Process (AHP) adalah memiliki sebuah hirarki fungsional dengan input utamanya persepsi manusia. Berikut adalah rumus AHP.

Dimana :

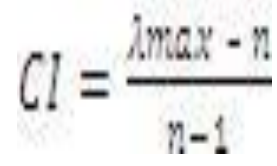

\section{CI = Consistency Index ( Rasio Penyimpangan Konsistensi ) \\ $\lambda_{\max }=$ Nilai eigen terbesar dari matriks berordo $n$ $n \quad=$ Jumlah elemen yang dibandingkan.}

Nilai $C I$ bernilai nol apabila terdapat standar untuk menyatakan apakah $C I$ menunjukkan matriks yang konsisten. Saat berpendapat bahwa suatu matriks yang dihasilkan dari perbandingan yang dilakukan secara acak merupakan suatu matriks yang tidak konsisten. Dari matriks acak didapatkan juga nilai Consistency Index yang disebut dengan Random Index (RI).

Dengan membandingkan $C I$ dengan $R I$ maka didapatkan patokan untuk menentukan tingkat konsistensi suatu matriks yang disebut dengan Consistency Ratio (CR) dengan rumus :

$$
C R=C I / R I
$$

Dimana :

$$
\begin{array}{ll}
C R & =\text { Consistency Ratio } \\
R I & =\text { Random Index }
\end{array}
$$

Dengan hirarki, suatu masalah kompleks dan tidak terstruktur dipecahkan ke dalam kelomok-kelompoknya dan diatur menjadi suatu bentuk hirarki.

\section{E. Algoritma Dijkstra}

Algoritma Dijkstra ini menyelesaikan masalah mencari sebuah lintasan terpendek dari vertex a ke vertex $\mathrm{z}$ dalam graph berbobot, bobot tersebut adalah bilangan positif jadi tidak dapat dilalui oleh node negatif, namun jika terjadi demikian, maka penyelesaian yang diberikan adalah infiniti atau jumlah tak terbatas. Algoritma Dijkstra melibatkan pemasangan label pada vertex. Misalkan $\mathrm{L}(\mathrm{v})$ menyatakan label dari vertex $\mathrm{v}$. Pada setiap pembahasan, beberapa vertex mempunyai label sementara dan yang lain mempunyai label tetap. Misalkan $\mathrm{T}$ menyatakan himpunan vertex yang mempunyai label sementara. Dalam menggambarkan algoritma tersebut kumpulan vertex yang mempunyai label tetap akan dilingkari. Selanjutnya jika $\mathrm{L}(\mathrm{v})$ adalah label tetap dari vertex $\mathrm{v}$, maka L(v) merupakan label sementara ke tetap. Pada bagian ini $\mathrm{L}(\mathrm{z})$ merupakan panjang kan lintasan terpendek dari a ke z. P pada algoritma Dijkstra node digunakan, karena algoritma Dijkstra menggunakan diagram pohon untuk penentuan jalur lintasan $\mathrm{n}$ terpendek dan menggunakan graph yang berarah [8].

Rumusan Algoritma Dijkstra (2.3)

$\mathrm{V}(\mathrm{G}) \quad=\{\mathrm{v} 1, \mathrm{v} 2, \mathrm{v} 3, . ., \mathrm{vn}\}$

$\mathrm{L} \quad=$ Himpunan node $\mathrm{V}(\mathrm{G})$ yang sudah terpilih dalam jalur terpendek

$\mathrm{D}(\mathrm{j}) \quad=$ Jumlah bobot jarak terkecil dari v1 ke vj

$\mathrm{W}(\mathrm{i}, \mathrm{j})=$ Jumlah bobot jarak terkecil dari $\mathrm{v} 1 \mathrm{ke} \mathrm{vj}$

Secara formal, algoritma Dijkstra untuk mencari jarak terpendek adalah :

$\mathrm{L}=\{\}$

$\mathrm{V}=\left\{\mathrm{v}_{2}, \mathrm{v}_{3}, \ldots, \mathrm{v}_{\mathrm{n}}\right\}$

Untuk $\mathrm{i}=2,3, \ldots, \mathrm{n}$, lakukan $\mathrm{D}(\mathrm{i})=\mathrm{w}(1, \mathrm{i})$

Selama vn $\underline{E}$ L lakukan :

a. Pilih node $\mathrm{v}_{\mathrm{k}} \mathrm{V}$-L dengan $\mathrm{D}(\mathrm{k})$ terkecil $\mathrm{L}=\mathrm{L} \cup\left\{\mathrm{v}_{\mathrm{k}}\right\}$

b. Untuk setiap vj V-L lakukan : Jika $D(j)>D(k)+w(k, j)$ maka ganti $D(j)$ dengan $\mathrm{D}(\mathrm{k})+\mathrm{w}(\mathrm{k}, \mathrm{j})$

\section{F. Data Flow Diagram}

Data flow diagram (DFD) merupakan alat yang menggambarkan aliran data melalui sistem dan kerja atau pengolahan yang dilakukan oleh sistem tersebut [9] . DFD adalah suatu model logika data atau proses yang dibuat untuk menggambarkan darimana asal data dan kemana tujuan data yang keluar dari sistem, dimana data disimpan, proses apa yang menghasilkan data tersebut dan interaksi antara data yang tersimpan dan proses yang dikenakan pada data tersebut [10]. DFD mempunyai keterbatasan yaitu tidak menunjukan proses perulangan atau loop, tidak 
menunjukan proses keputusan (decision), tidak menunjukkan proses perhitungan. Keterbatasan DFD ini dapat dipecahkan dengan menambah penggunaan operasional operator sehingga kemampuan DFD dapat lebih ditingkatkan [5].

\section{G. Google Maps API}

Google Maps API adalah sebuah library JavaScript yang memungkinkan dalam meng-embed Google Maps ke dalam halaman website [11]. Dengan menggunakan Google Maps API dapat menghemat waktu dan biaya untuk membangun aplikasi peta digital yang handal, sehingga dapat fokus hanya pada basis data saja. Untuk dapat mengakses Google Maps, harus melakukan pendaftaran API key terlebih dahulu dengan data pendaftaran berupa nama domain web yang kita bangun. Google Maps dapat digabungkan dengan beberapa bahasa pemograman lain seperti PHP, Perl, CGI dan lain-lain. Sehingga dengan Google Maps API ini akan banyak tercipta di banyak aplikasi. Google Maps API adalah library yang bersifat open source sehingga aplikasi yang dihasilkan dengan Google Maps adalah aplikasi open source juga.

\section{H. Website}

Website merupakan kumpulan halaman web yang saling terhubung dan file saling terkait [12]. Website terdiri dari page atau halaman, dan kumpulan halaman yang dinamakan homepage. Homepage berada pada posisi teratas, dengan halaman - halaman terkait berada di bawahnya. Menurut Website adalah suatu metode untuk menampilan informasi di internet, baik berupa teks, gambar, suara maupun video yang interaktif dan mempunyai kelebihan untuk menghubungkan (link) satu dokumen dengan dokumen lainnya (hypertext) yang dapat diakses melalui sebuah browser [13].

\section{Pengujian Perangkat Lunak}

Pengujian perangkat lunak merupakan suatu teknik yang digunakan menguji apakah sebuah perangkat lunak yang dihasilkan telah sesuai dengan yang diharapkan atau belum. Pengujian adalah proses eksekusi suatu program untuk menemukan kesalahan sebelum digunakan oleh pengguna akhir (end-user) [14].

\section{J. Pengujian User Acceptance Testing}

User acceptance testing merupakan pengujian yang dilakukan oleh end - user dimana user tersebut adalah staff / karyawan perusahaan yang langsung berinteraksi dengan sistem dan di lakukan verifikasi apakah fungsi yang ada telah berjalan sesuai dengan kebutuhan / fungsinya [15]. (acceptance testing biasanya berusaha menunjukkan bahwa sistem telah memenuhi persyaratan persyaratan tertentu [16]. Pada pengembangan software dan hardware komersial, acceptance test biasanya di sebut juga "alpha tests" (yang di lakukan oleh pengguna in-house) dan "beta tests" (yang dilakukan oleh pengguna yang sedang menggunakan atau akan menggunakan sistem tersebut). Alpha dan beta test biasanya juga menunjukkan bahwa produk sudah siapun untuk dijual atau dipasarkan. Acceptance testing mencakup data, environment dan skenario yang sama atau hampir sama pada saat live yang biasanya berfokus pada skenario penggunaan produk tertentu.

\section{K. Pengujian Black Box}

Metode pengujian black box merupakan pengujian yang dipilih berdasarkan spesifikasi masalah tanpa memperhatikan detail internal dari program, pengujian dilakukan untuk memeriksa apakah program dapat berjalan dengan benar [17].

\section{METODOLOGI PENELITIAN}

\section{A. Metodologi Penelitian}

Metodologi penelitian merupakan suatu perencanaan penelitian yang akan dilakukan secara sistematis dan ilmiah. Pada penelitian ini, dibangun dengan mendesain perencanaan penelitian sehingga mudah untuk dilakukan. Metodologi penelitian tersebut diilustrasikan pada gambar 1 berikut.

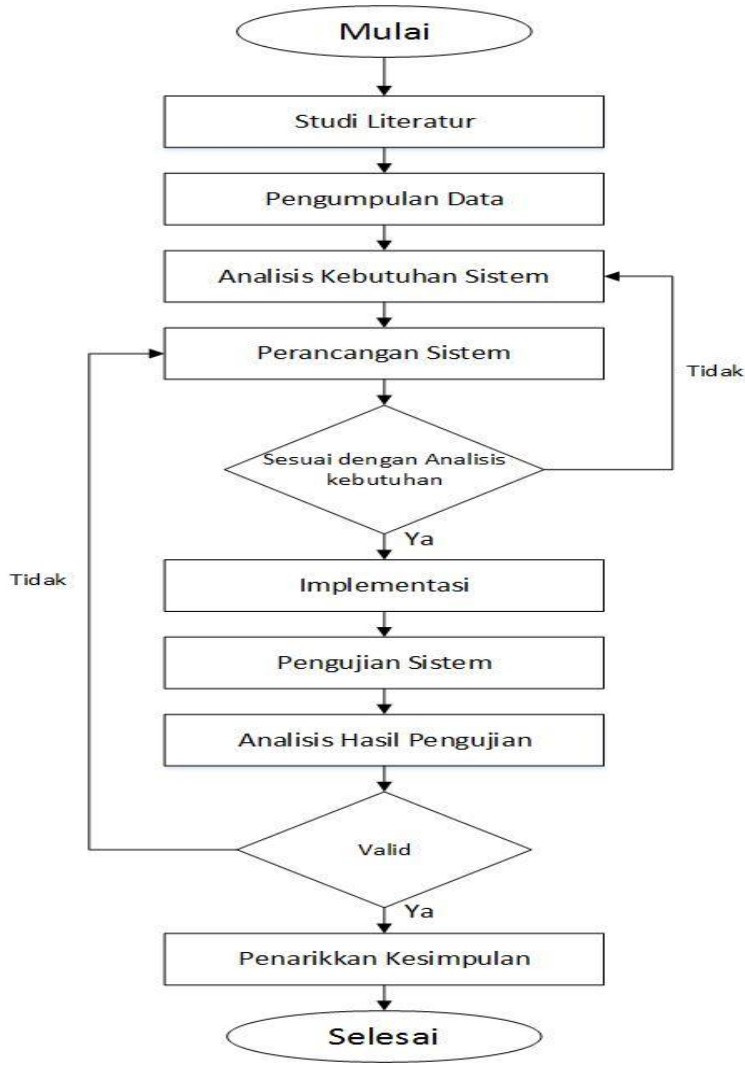

Gambar 1. Diagram alir penelitian

\section{B. Data Penelitian}

Data yang dikumpulkan untuk menunjang penelitian ini di peroleh dari Dinas Pariwisata Kabupaten Bengkayang. Adapun data yang diperlukan antara lain titik koordinat tempat wisata, fasilitas yang ada dari tempat wisata, jumlah pengujung, foto atau gambar tempat wisata dan hal-hal yang berkaitan dengan system informasi yang dapat diperoleh dari berbagai sumber baik melalui buku, website, atau sumber informasi lainnya.

\section{Perancangan Arsitektur Sistem}

Arsitektur sistem merupakan sistem yang dapat digunakan untuk mengelolah data tempat wisata, 
menampilkan rekomendasi wisata dan rute jalur terdekat dengan menggunakan metode Analytical Hierarchy Process (AHP) dan algoritma Dijkstra. Sebagai media mempromosikan wisata yang ada di kabupaten Bengkayang. Dalam sistem ini terdapat dua tipe user yaitu admin dan pengunjung. Admin merupakan pengguna yang dapat mengatur atau menginput data yang akan di tampilkan pada website. Sedangkan pengujung dapat mengakses website melihat rute jalur dan situs wisata terbaik serta informasi yang berkaitan tentang objek wisata Kabupaten Bengkayang. Arsitektur system tersebut diilustrasikan pada Gambar 1 berikut.

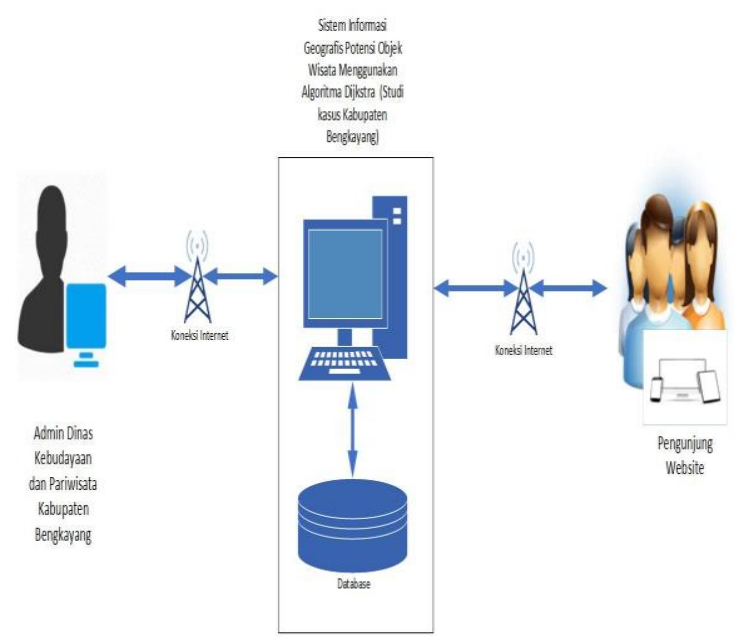

Gambar 2. Arsitektur sistem

\section{Diagram Konteks}

Diagram konteks sistem adalah diagram yang memberi gambaran seluruh jaringan terhadap seluruh masukan dan keluaran sistem yang dimaksudkan untuk mengambarkan sistem yang sedang berjalan.

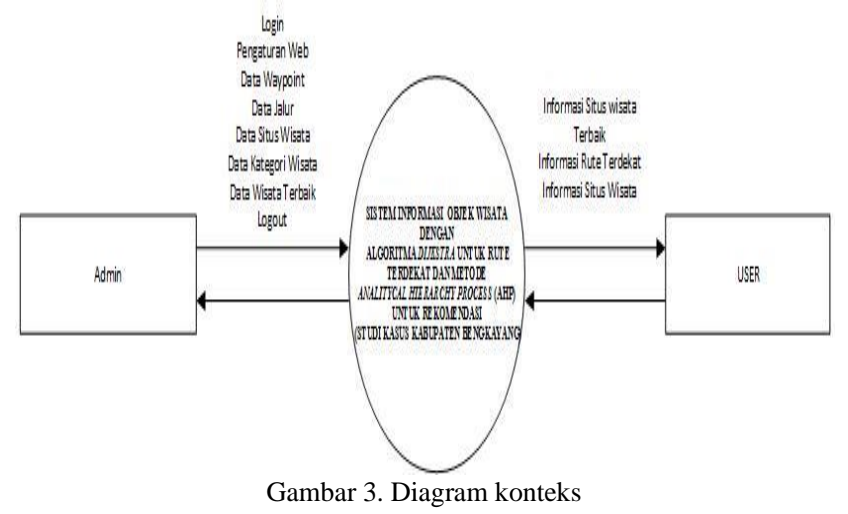

\section{E. Perancangan Antarmuka Sistem}

Perancangan antarmuka (interface) dirancang sebagai gambaran awal sistem yang akan dibangun. Perancangan antarmuka sistem meliputi beberapa pengguna admin dan user. Antarmuka sistem dirancang dalam bentuk layout yang memiliki fungsi tertentu sesuai dengan proses-proses yang ada. Layout-layout tersebut diakses melalui menu pada layout utama. Struktur antarmuka sistem dapat dilihat pada gambar 4 .

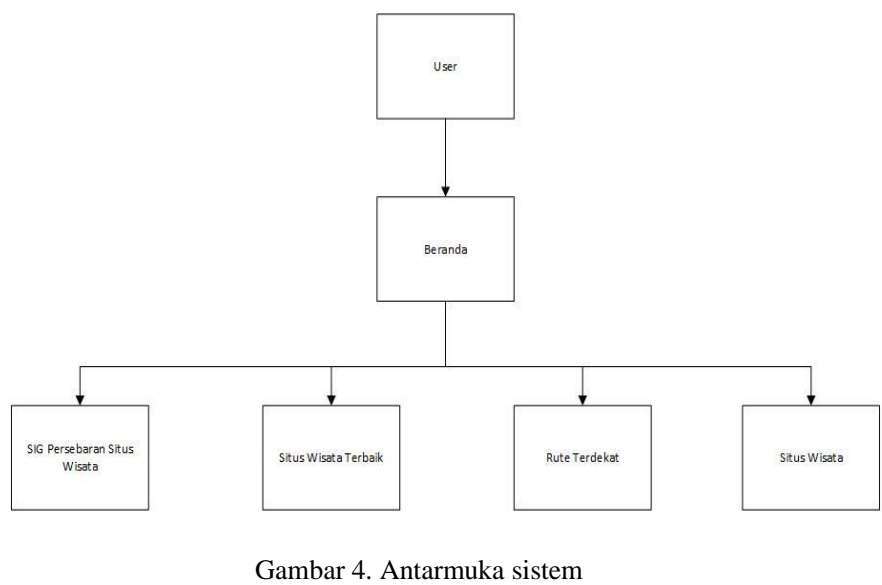

IV. HASIL DAN PENGUJIAN

Berdasarkan hasil analisis dan pengujian terhadap sistem informasi objek wisata dengan algoritma Djisktra untuk rute terdekat dan metode analitycal hierarchy process (AHP) untuk rekomendasi dapat disimpulkan bahwa aplikasi ini dapat menghasilkan urutan nilai preferensi terbesar hingga preferensi terkecil untuk merekomendasikan objek wisata terfarorit dan rute terdekat menuju tempat wisata. Berikut ini adalah penjelasan mengenai hasil perancangan antarmuka dari aplikasi yang dirancang.

\section{A. Antarmuka Halaman Login}

Antarmuka halaman login merupakan form yang muncul saat user dan admin menjalankan website. Antarmuka halaman login digunakan untuk proses autentikasi user dan admin sebelum mengakses website dengan memasukkan username dan password. Antarmuka halaman login dapat dilihat pada gambar 5.

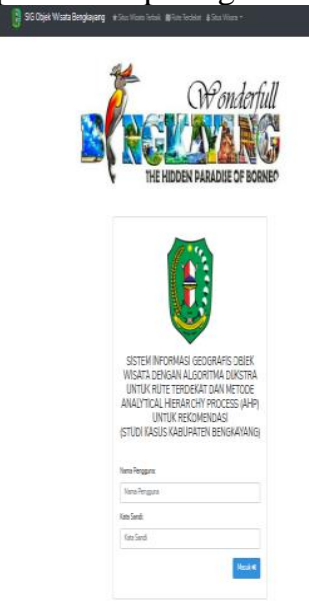

Gambar 5. Antarmuka login

\section{B. Antarmuka Situs Wisata}

Antarmuka situs wisata merupakan halaman informasi data daftar situs wisata yang ada di Kabupaten Bengkayang. Tampilan halaman situs wisata dapat dilihat pada gambar 6. 


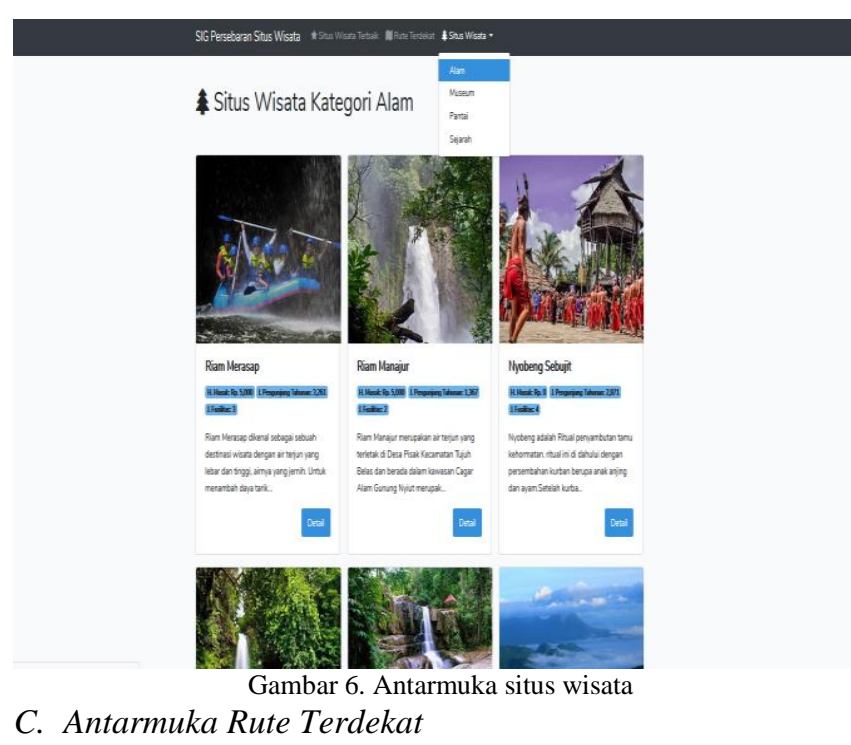

Antarmuka rute jalur terdekat, user meng-input titik lokasi awal dan lokasi tujuan tempat wisata maka sistem akan menampilkan rute jalur terdekat menuju tempat wisata. Tampilan halaman antarmuka peta rute jalur terdekat dapat dilihat pada gambar 7 .

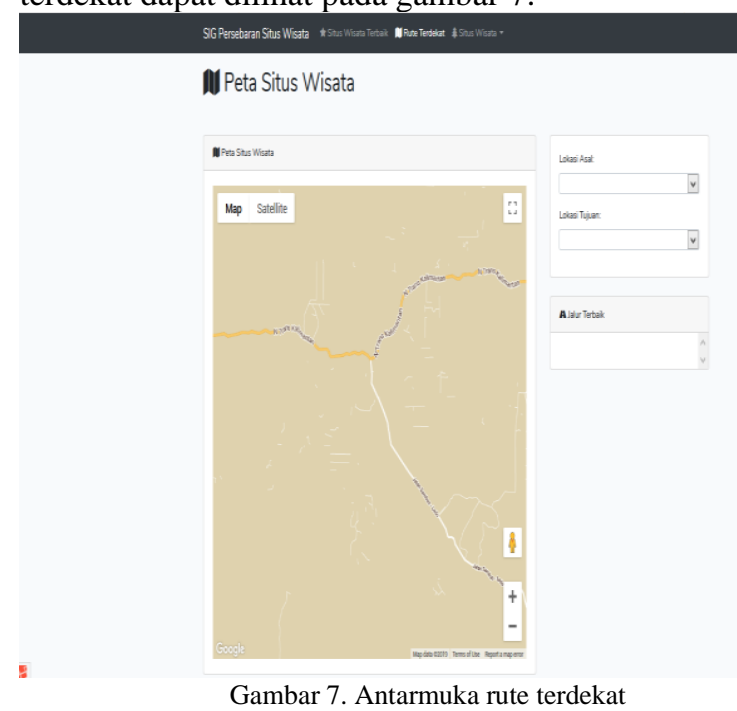

\section{Antarmuka Perhitungan AHP}

Antarmuka perhitungan AHP. admin dapat melihat langkah perhitungan metode AHP dalam mencari hasil perhitungan wisata terbaik. Tampilan halaman perhitungan AHP dapat dilihat pada gambar 8.

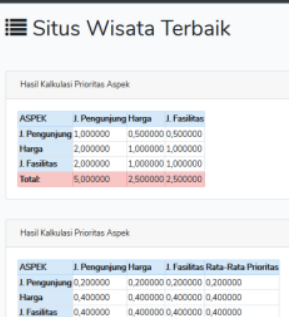

Gambar 8. Antarmuka perhitungan AHP

\section{Pengujian}

Pada penelitian dilakukan dua jenis pengujian yaitu pengujian black box dan pengujian user acceptance testing

\section{1) Pengujian Black Box}

Black box pada perangkat lunak dilakukan untuk menguji kesesuaian antara masukan dengan hasil yang ditampilkan pada aplikasi. Pengujian ini berfokus pada spesifikasi fungsional dari software, menguji kondisi input program berdasarkan apa yang dilihat, hanya fokus terhadap fungsionalitas dan output. Pengujian ini perlu dilakukan untuk melihat respon yang diberikan oleh sistem saat melakukan proses input data.

- Pengujian login.

Pengujian input data dilakukan pada halaman login. Input data yang diuji adalah saat memasukkan username dan password. Lihat Tabel 1.

TABEL I

PENGUJIAN HASIL UJI INPUT LOGIN

\begin{tabular}{|c|c|c|l|}
\hline \multicolumn{2}{|c|}{ Skenario Pengujian } & \multicolumn{1}{|c|}{$\begin{array}{c}\text { Hasil } \\
\text { Uji }\end{array}$} & \multicolumn{1}{c|}{$\begin{array}{c}\text { Hasil Yang } \\
\text { Diharapkan } \\
\text { (Keterangan) }\end{array}$} \\
\hline 1 & Input data kosong & $\begin{array}{c}\text { Tidak } \\
\text { Berhasil }\end{array}$ & $\begin{array}{l}\text { Sistem akan menolak jika } \\
\text { disimpan, pesan } \\
\text { menampilkan dan } \\
\text { kesalahan: } \\
\text { "kolom ini wajib di isi" }\end{array}$ \\
\hline 2 & $\begin{array}{c}\text { Input data salah } \\
\text { satu kosong }\end{array}$ & $\begin{array}{l}\text { Tidak } \\
\text { Berhasil }\end{array}$ & $\begin{array}{l}\text { Sistem akan menolak jika } \\
\text { disimpan, pesan } \\
\text { menampilkan } \\
\text { kesalahan: } \\
\text { "kolom ini wajib di isi" }\end{array}$ \\
\hline 3 & $\begin{array}{c}\text { Input semua data } \\
\text { diisi }\end{array}$ & Berhasil & $\begin{array}{l}\text { Berhasil Login dan Masuk } \\
\text { ke Aplikasi }\end{array}$ \\
\hline 4 & $\begin{array}{c}\text { Input username } \\
\text { /password tidak } \\
\text { benar }\end{array}$ & Tidak & $\begin{array}{l}\text { Sistem akan menolak jika } \\
\text { disimpan, dan } \\
\text { menampilkan pesan } \\
\text { kesalahan: } \\
\text { "Username/Password } \\
\text { Salah" }\end{array}$ \\
\hline 5 & $\begin{array}{c}\text { Input username \& } \\
\text { password }\end{array}$ & Berhasil & $\begin{array}{l}\text { Berhasil Login dan Masuk } \\
\text { ke Aplikasi }\end{array}$ \\
\hline
\end{tabular}

- Pengujian Pengaturan Gambar Slide Web

Pengujian input gambar slide web dilakukan pada halaman amdin. Input data yang diuji adalah saat memasukkan data gambar objek wisata Bengkayang. Lihat Tabel 2.

TABEL I1

PENGUJIAN HASIL UJI PENGATURAN GAMBAR SLIDE WEB

\begin{tabular}{|c|c|c|c|}
\hline \multicolumn{2}{|c|}{$\begin{array}{c}\text { Skenario } \\
\text { Pengujian }\end{array}$} & $\begin{array}{c}\text { Hasil } \\
\text { Uji }\end{array}$ & $\begin{array}{c}\text { Hasil Yang Diharapkan } \\
\text { (Keterangan) }\end{array}$ \\
\hline 1 & $\begin{array}{c}\text { Input data } \\
\text { kosong }\end{array}$ & $\begin{array}{c}\text { Tidak } \\
\text { Berhasil }\end{array}$ & $\begin{array}{l}\text { Sistem akan menolak jika disimpan, } \\
\text { dan menampilkan pesan kesalahan: } \\
\text { "kolom ini wajib di isi" }\end{array}$ \\
\hline 2 & $\begin{array}{c}\text { Input data } \\
\text { salah satu } \\
\text { kosong }\end{array}$ & $\begin{array}{c}\text { Tidak } \\
\text { Berhasil }\end{array}$ & $\begin{array}{l}\text { Tidak berhasil menyimpan dan dan } \\
\text { menampilkan pesan kesalahan:“ } \\
\text { kolom ini wajib di isi" }\end{array}$ \\
\hline 3 & $\begin{array}{c}\text { Input } \\
\text { semua data } \\
\text { diisi }\end{array}$ & Berhasil & $\begin{array}{l}\text { Sistem akan menyimpan data dan } \\
\text { menampilkan pesan: "Data berhasil } \\
\text { disimpan" }\end{array}$ \\
\hline
\end{tabular}


- Pengujian Waypoint

Pengujian Waypoint adalah pengujian data titik kordinat tempat wisata. Lihat Tabel 3.

TABEL III

PENGUJIAN HASIL UJI WAYPOINT

\begin{tabular}{|c|c|c|c|}
\hline \multicolumn{2}{|c|}{$\begin{array}{c}\text { Skenario } \\
\text { Pengujian }\end{array}$} & $\begin{array}{c}\text { Hasil } \\
\text { Uji }\end{array}$ & $\begin{array}{c}\text { Hasil Yang Diharapkan } \\
\text { (Keterangan) }\end{array}$ \\
\hline 1 & $\begin{array}{c}\text { Input } \\
\text { data } \\
\text { kosong }\end{array}$ & $\begin{array}{c}\text { Tidak } \\
\text { Berhasil }\end{array}$ & $\begin{array}{c}\text { Sistem akan menolak jika disimpan, } \\
\text { dan menampilkan pesan kesalahan: } \\
\text { "kolom ini wajib di isi" }\end{array}$ \\
\hline 2 & $\begin{array}{c}\text { Input } \\
\text { data } \\
\text { salah } \\
\text { satu } \\
\text { kosong }\end{array}$ & Tidak & $\begin{array}{c}\text { Sistem akan menolak jika disimpan, } \\
\text { dan menampilkan pesan kesalahan: } \\
\text { "kolom ini wajib di isi" }\end{array}$ \\
\hline 3 & $\begin{array}{c}\text { Input } \\
\text { semua } \\
\text { data diisi }\end{array}$ & Berhasil & Sistem akan menyimpan data dan \\
menampilkan pesan: \\
"Data berhasil disimpan"
\end{tabular}

- Pengujian Input Jalur

Pengujian input data jalur dilakukan dengan menambah titik awal dan titik tujuan. Lihat Tabel 4.

TABEL IV

PENGUJIAN HASIL UJI JALUR

\begin{tabular}{|c|c|c|c|}
\hline \multicolumn{2}{|c|}{$\begin{array}{c}\text { Skenario } \\
\text { Pengujian }\end{array}$} & $\begin{array}{c}\text { Hasil } \\
\text { Uji }\end{array}$ & $\begin{array}{c}\text { Hasil Yang Diharapkan } \\
\text { (Keterangan) }\end{array}$ \\
\hline 1 & $\begin{array}{c}\text { Input } \\
\text { data } \\
\text { kosong }\end{array}$ & $\begin{array}{c}\text { Tidak } \\
\text { Berhasil }\end{array}$ & $\begin{array}{c}\text { Sistem akan menolak jika disimpan, dan } \\
\text { menampilkan pesan kesalahan: } \\
\text { "kolom ini wajib di isi" }\end{array}$ \\
\hline 2 & $\begin{array}{c}\text { Input } \\
\text { data diisi }\end{array}$ & Berhasil & $\begin{array}{c}\text { Sistem akan menyimpan data dan } \\
\text { menampilkan pesan: } \\
\text { "Data berhasil disimpan" }\end{array}$ \\
\hline
\end{tabular}

- Pengujian Input Situs

Pengujian input data situs wisata dilakukan dengan menambahkan situs wisata.Lihat Tabel 5.

TABEL V

PENGUJIAN HASIL UJI SITUS

\begin{tabular}{|c|c|c|c|}
\hline \multicolumn{2}{|c|}{$\begin{array}{l}\text { Skenario } \\
\text { Pengujian }\end{array}$} & \multirow{2}{*}{$\begin{array}{c}\begin{array}{c}\text { Hasil } \\
\text { Uji }\end{array} \\
\text { Tidak } \\
\text { Berhasil }\end{array}$} & \multirow{2}{*}{\begin{tabular}{l}
\multicolumn{1}{c}{$\begin{array}{c}\text { Hasil Yang Diharapkan } \\
\text { (Keterangan) }\end{array}$} \\
$\begin{array}{l}\text { Sistem akan menolak jika disimpan, dan } \\
\text { menampilkan pesan kesalahan: } \\
\text { "kolom ini wajib di isi" }\end{array}$ \\
\end{tabular}} \\
\hline 1 & $\begin{array}{c}\text { Input } \\
\text { data } \\
\text { kosong }\end{array}$ & & \\
\hline 2 & $\begin{array}{c}\text { Input } \\
\text { data } \\
\text { salah } \\
\text { satu } \\
\text { kosong }\end{array}$ & $\begin{array}{c}\text { Tidak } \\
\text { Berhasil }\end{array}$ & $\begin{array}{l}\text { Sistem akan menolak jika disimpan, dan } \\
\text { menampilkan pesan kesalahan: } \\
\text { "kolom ini wajib di isi" }\end{array}$ \\
\hline 3 & $\begin{array}{c}\text { Input } \\
\text { semua } \\
\text { data } \\
\text { diisi }\end{array}$ & Berhasil & $\begin{array}{l}\text { Sistem akan menyimpan data dan } \\
\text { menampilkan pesan: } \\
\text { "Databerhasil disimpan" }\end{array}$ \\
\hline
\end{tabular}

- $\quad$ Pengujian Input Kategori

Pengujian input data kategori wisata dilakukan dengan menambahkan kategori wisata. Lihat Tabel 6.

TABEL V1

PENGUJIAN HASIL UJI KATEGORI

\begin{tabular}{|c|c|c|c|}
\hline \multicolumn{2}{|c|}{$\begin{array}{c}\text { Skenario } \\
\text { Pengujian }\end{array}$} & $\begin{array}{c}\text { Hasil } \\
\text { Uji }\end{array}$ & $\begin{array}{c}\text { Hasil Yang Diharapkan } \\
\text { (Keterangan) }\end{array}$ \\
\hline 1 & $\begin{array}{c}\text { Input data } \\
\text { kosong }\end{array}$ & $\begin{array}{c}\text { Tidak } \\
\text { Berhasil }\end{array}$ & $\begin{array}{c}\text { Sistem akan menolak jika disimpan, dan } \\
\text { menampilkan pesan kesalahan: } \\
\text { "kolom ini wajib di isi" }\end{array}$ \\
\hline
\end{tabular}

\begin{tabular}{|c|c|c|c|}
\hline 2 & $\begin{array}{c}\text { Input data } \\
\text { diisi }\end{array}$ & Berhasil & $\begin{array}{c}\text { Sistem akan menyimpan data dan } \\
\text { menampilkan pesan: } \\
\text { "Data berhasil disimpan" }\end{array}$ \\
\hline
\end{tabular}

2) Hasil Pengujian User Acceptance Testing

Pengujian user acceptance testing dilakukan dengan mengajukan aspek pertanyaan kepada responden. Pengujian ini dilakukan untuk menguji sejauh mana pengguna dapat menggunakan sistem ini. Jumlah pertanyaaan 17 dan jumlah responden pada penelitian ini adalah dari 30 responden yang menjawab terbagi menjadi 7 orang responden staf dinas pariwisata, 10 responden masyarakat umum, 13 responden mahasiswa.Hasil pengujian ini dihitung dengan skala likert dari hasil pengujian menunjukkan nilai 2228 dengan niali yang sangat positif berarti aplikasi di nilai berhasil.

Hasil perhitungan dapat dilihat pada tabel 7 dengan perhitungan sebagai berikut :

TABEL V1

PENGUJIAN HASIL UJI UAT

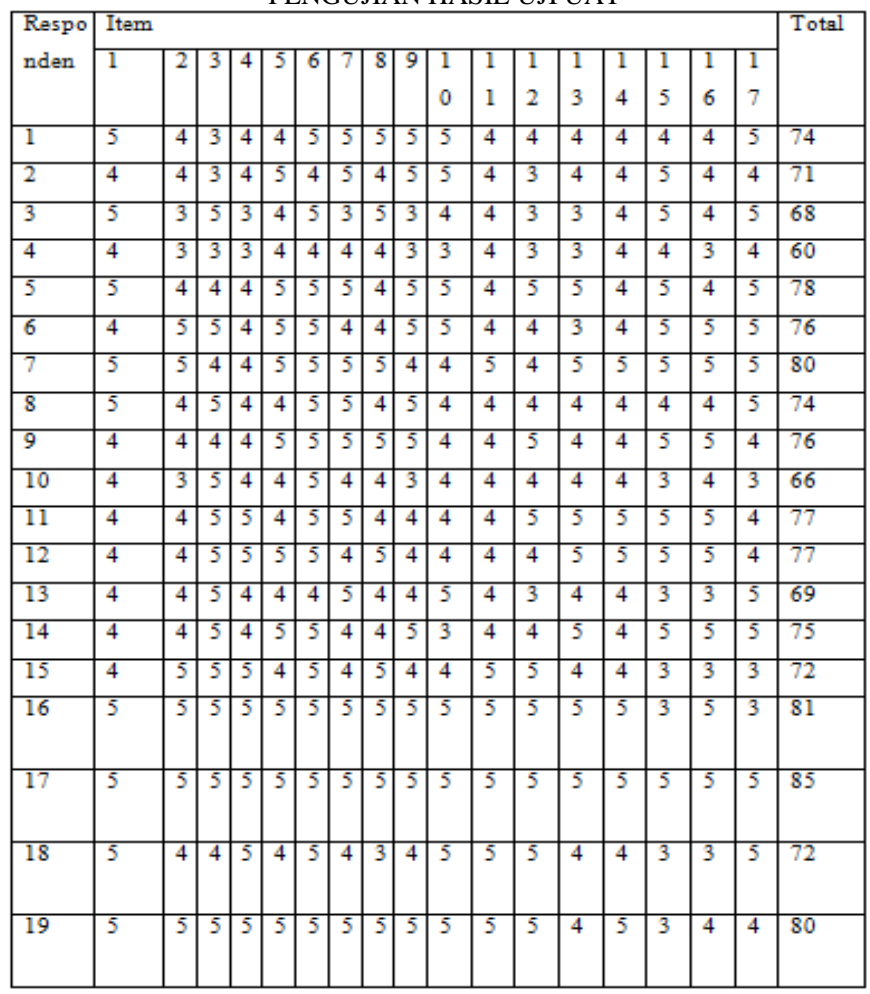




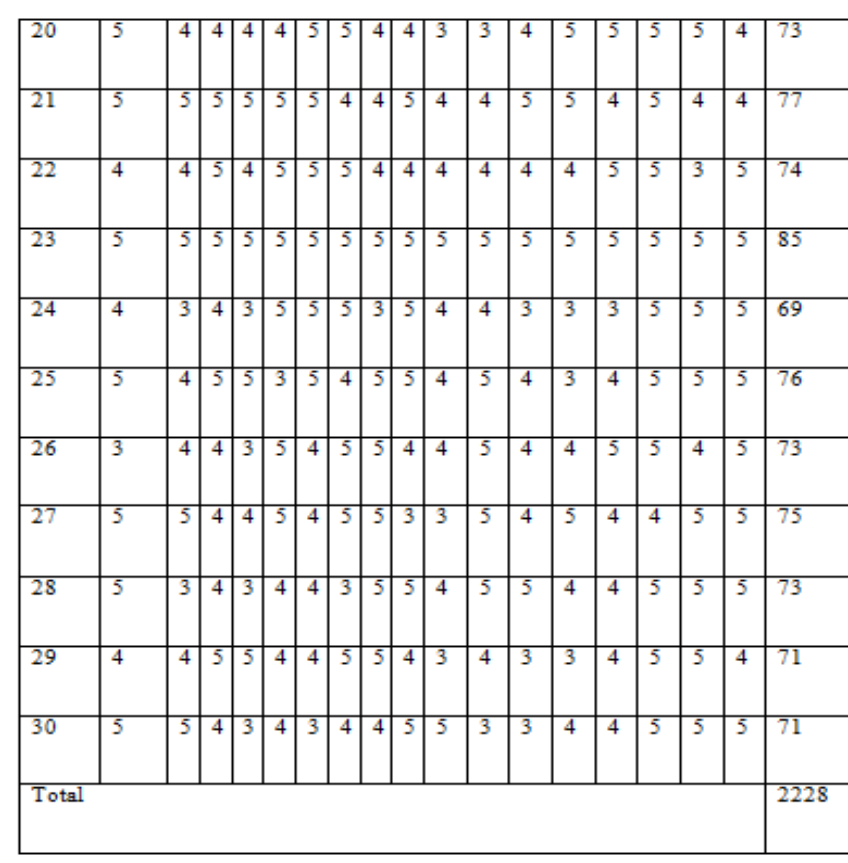

\section{KESIMPULAN}

Kesimpulan yang didapat dari hasil metodologi penelitian, analisis sistem, perancangan dan pengujian terhadap sistem informasi objek wisata dengan mengunakan algoritma dijkstra dan metode analitycal hierarchy process (AHP) adalah sebagai berikut. Sistem ini memberikan informasi rute jalur terdekat dan rekomendasi objek wisata yang ada di Kabupaten Bengkayang. Dari hasil pengujian dapat User Acceptance Testing (UAT) nilai yang di peroleh sangat positif dengan nilai 2228 yang berarti website dinilai berhasil. Hasil pengujian Black Box dapat di simpulkan bahwa sistem informasi objek wisata sudah berfungsi dengan baik dan sesuai dengan yang di harapkan.

Adapun hal yang menjadi saran dalam pengembangan sistem ini agar lebih baik lagi adalah sebagai berikut. Sistem dapat dikembangkan dengan menggunakan metode yang berbeda untuk mengetahui perbedaan hasil rekomendasi untuk masalah pemilihan wisata terfavorit. Sistem dapat di integrasikan dengan sistem lainnya yang ada di dinas pariwisata Kabupaten Bengkayang.

\section{DAFTAR PUSTAKA}

[1] A. Gusmão, S. H. Pramono, and S. Sunaryo, "Sistem Informasi Geografis Pariwisata Berbasis Web Dan Pencarian Jalur Terpendek Dengan P Algoritma Dijkstra," J. EECCIS, vol. 7 no. 2, pp. 125-130, 2013

[2] S. S. Saputro, "Perancangan Aplikasi GIS Pencarian Rute Terpendek Peta Wisata di Kota Manado Berbasis Mobile WEB dengan Algoritma Dijkstra," Tek. Inform. Univ. Dian Nuswantoro, Semarang, 2013.

[3] M. I. Kamil, H. Anra, and H. Sastypratiwi, "Rancang Bangun Aplikasi Pencarian Rute Terpendek Lokasi Wisata Kuliner Kota Pontianak Berbasis Mobile," J. Sist. dan Teknol. Inf., vol. 3, no. 3, pp. 191-196.

[4] D. Prayogi, "Pengembangan Potensi Wisata Kuliner Kota Malang Berbasis Sumber Daya Lokal,” J. Pariwisata Pesona, vol. 2, no. 1, p. 13, 2017.

[5] H. Jogiyanto, Analisis dan Desain Sistem Informasi Yogyakarta: Andi Offset. Yogyakarta: Andi Offset, 2005.

[6] S. Azhar, "Sistem Informasi Manajemen: Konsep dan
2004.

A. Amborowati, "Sistem Penunjang Keputusan Pemilihan Perumahan dengan Metode AHP Menggunakan Expert Choice," J. DASI, vol. 9, no. 1, 2008.

[8] L. J. E. Dewi, "Pencarian Rute Terpendek Tempat Wisata Di Bali Dengan Menggunakan Algoritma Dijkstra," J. Fak. Huk. UII, 2010.

[9] N. A. Y. Ramadhani, "Pembangunan Sistem Informasi Penerimaan Siswa Baru Di Sekolah Menengah Kejuruan AlIrsyad Tegal," Speed-Sentra Penelit. Eng. dan Edukasi, vol. 3 , no. 3, 2012.

[10] I. H. Kristanto, Konsep \& Perancangan Database. Yogyakarta: Penerbit Andi, 1994.

[11] F. Mahdia and F. Noviyanto, "Pemanfaatan Google Maps API untuk pembangunan sistem informasi manajemen bantuan logistik pasca bencana alam berbasis mobile web (studi kasus: badan penanggulangan bencana daerah Kota Yogyakarta)," $J$. Sarj. Tek. Inform., vol. 1, no. 1, pp. 162-171, 2013.

D. E. Hendrianto, "Pembuatan Sistem Informasi Perpustakaan Berbasis Website Pada Sekolah Menegah Pertama Negeri 1 Donorojo Kabupaten Pacitan," IJNS-Indonesian J. Netw. Secur., vol. 4, no. 3, 2013.

[13] B. L. Nuryanti, "Model Pembelajaran E-Learning Melalui Homepage Sebagai Media Pembelajaran Sehingga Diharapkan Dapat Meningkatkan Minat Dan Kreativitas Siswa," J. ABMAS (Media Komun. dan Inf. Pengabdi. Kpd. Masyarakat), vol. 9, pp. 1-7, 2009.

[14] E. Arbie, Pengantar Sistem Informasi Manajemen, vol. 1. Jakarta: Bina Alumni Indonesia, 2000.

[15] H. Supriyono, R. F. Rahmadzani, M. Adhantoro, and A. K. Susilo, "Rancang bangun media pembelajaran dan game edukatif pengenalan aksara jawa 'pandawa,"' 2016.

[16] H. Ekasaputra, "Sistem Informasi Geografis Pemetaan Jaringan Pipa Air Berbasis MAPBOX GL JS (Studi Kasus: Dinas Pekerjaan Uumum dan Penataan Ruang Provinsi Riau)," 2018.

[17] R. S. Pressman, Rekayasa Perangkat Lunak Pendekatan Praktisi (Buku Satu). Yogyakarta: Penerbit Andi, 2002. 